\title{
Teacher Roles in Primary School Mathematics Curricula of the Republican Period
}

\author{
Ayşe ÖZTÜRK \\ Department of Primary Education, The University of Gaziantep, Turkey
}

\begin{tabular}{|c|c|}
\hline \multicolumn{2}{|c|}{$\begin{array}{c}\text { MehmetFatih ÖZMANTAR* } \\
\text { Department of Primary Education, The University of Gaziantep, Turkey }\end{array}$} \\
\hline Article history & This study aims to examine the teacher roles in primary school \\
\hline $\begin{array}{l}\text { Received: } \\
09.08 .2016\end{array}$ & $\begin{array}{l}\text { mathematics curricula employed during the Republican period. We } \\
\text { identified ten official primary school mathematics curricula documents }\end{array}$ \\
\hline $\begin{array}{l}\text { Received in revised form: } \\
11.09 .2016\end{array}$ & $\begin{array}{l}\text { issued between the period of } 1924 \text { and } 2015 \text {. All the documents are put } \\
\text { to examination through the content analysis method in order to identify } \\
\text { the roles assigned to the teachers. For the analysis of the data, reliability }\end{array}$ \\
\hline $\begin{array}{l}\text { Accepted: } \\
20.09 .2016\end{array}$ & $\begin{array}{l}\text { study was performed. The analysis revealed ten different categories of } \\
\text { roles defined for teachers. These categories are related to the }\end{array}$ \\
\hline Key words: & development of (mathematical) thinking skills, remediation of student \\
\hline $\begin{array}{l}\text { mathematics teaching, teacher } \\
\text { roles, historical analysis, } \\
\text { mathematics curriculum }\end{array}$ & $\begin{array}{l}\text { deficiencies, supporting affective qualities, creating effective teaching } \\
\text { environments and to the issue of equity. Our analysis suggests an } \\
\text { historical perspective to understand the teacher roles that have and/or } \\
\text { have not changed during the Republican period. Hence this study } \\
\text { provides an opportunity to evaluate the teacher roles assumed in the } \\
\text { official curricula documents for teaching mathematics during the } \\
\text { Republican Period from a historical perspective. }\end{array}$ \\
\hline
\end{tabular}

\section{Introduction}

Mathematical knowledge and skills are important tools for adults and children to make sense of both the physical and social world (National Council for Curriculum and Assessment[NCCA], 1999). It is a necessity for daily life, science, technology, engineering, financial literacy and many types of employment (National Council of Teacher of Mathematics [NCTM], 2014). Mathematics education is vital for economic, social, technological and scientific development of modern societies (NCCA, 1999). Countries are working on national mathematical curricula in order to improve the quality of mathematics education and provide students with the mathematical knowledge, skills and values that they are assumed to need in the rapidly changing world.

In order to make the mathematics education more efficient, curricula are periodically evaluated (NCTM, 2000) and changes, which are sometimes at a reform level, are introduced. Certain arrangements in the teaching-learning process take place and teachers are of vital importance for reaching the desired learning outputs with these changes (Klapper et al., 1994). Teachers, as practitioners of changes in this process, need to understand the dimensions of the change; expected to adopt their roles and to reflect them onto the teachinglearning process (Darling-Hammond, 1998). Teachers, who will be the practitioners of the educational reforms, and their approach to the reforms, have a direct effect on the results of 
the changes due to their strategic roles. Teachers' perception and implementation of the educational reform actually answers whether the reform has achieved the goals (Sikes, 1992, cf. Han, 2013, p.60). Especially reforms require rapid adaptation in addition to a fast and radical change in teacher roles (Henson, 2006). Hence, teachers' understanding, appropriation and implementation of these roles are vital to reach the desired (by the reforms) learning outputs.

Teacher roles are affected and shaped by many factors such as the teaching philosophy on which curricula are based, the design approach, dominant learning theory, and the teaching strategy. For instance, for an essentialist perspective, the teacher is in the center of teaching. The teacher who performs the teaching is active while the students are passive. The teacher is responsible for the transmission of correct information' to the students while the students are responsible for memorizing, revising and performing what is told. From a progressive perspective, the teacher acts as a guide and is responsible for arranging a learning environment by taking into account the interests, needs and skills of the students whom are assumed to learn by doing and experiencing (Ergün, 2009; Demirel, 2006; Sönmez, 2002). The effect of teaching strategies is also all too apparent on teachers' roles. Consider, for instance, expository teaching strategy in which the teacher is at the center and the provider of information in a teaching-learning process (Ormrod, 2003). In the discovery teaching strategy, the students construct abstractions while the teacher acts as a guide (Mayer, 2002).

It becomes important to have a historical perspective in understanding the changes in teacher roles appropriately. This is because there is a curriculum in practice prior to each so-called 'innovative' mathematics teaching movement and it is necessary to know the former processes well in order for a true understanding of the nature and effect of the changes. Historical perspective provides an understanding with regard to the quality and content of 'new' mathematics teaching movement in terms of pedagogy and standards (WalmsleyAngela, 2003). According to Ornstein and Hunkins (2004), understanding the historical background is necessary for shedding light on existing pedagogical practices, enabling the practitioners to understand the relationship between what student learned in the past and what they are learning now, making curriculum experts and educators avoid repeating their previous mistakes and enabling them to prepare for a better future. Accordingly, it can be said that examining teacher roles in mathematical curricula within historical context is important for an understanding of mathematics teaching-learning approaches. Such an analysis also provides information about the matters that were found successful in past practices and continued to exist or those that were found unsuccessful and aborted. Hence, it might become possible to increase the quality based on teacher activity during the implementation process.

However, there does not appear any study focusing on a comparative analysis of teacher roles in primary school mathematics curricula in Turkey. We believe that research efforts in this direction can certainly contribute to fill this gap. Such efforts could also create a useful base for curriculum developers by providing a holistic understanding about the mathematics teaching approaches in Turkey.

The purpose of this study is to examine teacher roles in the primary school mathematics curricula of the Republican Period in a comparative manner. To this end, we more specifically, attend to the questions of whether teacher roles have changed; and if so, what kind of changes has taken place throughout the history of Republic.

Before moving on to this examination, the historical development of the mathematics curricula in the Republican period will be briefly presented. Then the method of the study will 
be explained. The teacher roles determined in the curriculum analysis are explained in the findings. Finally, the teacher roles identified in the official curricula documents are evaluated based on the findings.

\section{Primary mathematics curricula developed during the Republican period}

The mathematics curriculum at primary level has undergone 10 major changes throughout the history of the Republic and hence, ten different curricula have been in use during this period. They were developed in 1924, 1926, 1936, 1948, 1968, 1983, 1990, 1998, 2005 and 2015 (Ergün et al., 2015). The 1924 curriculum was a transitional curriculum that was put into practice immediately after the foundation of the Republic. After being implemented for a short period of time, it was renewed in 1926. The 1926 curriculum, which was based on the principles of comprehensive education, was not as successful as expected and it was often criticized due to the lack of connections among the topics and difficulties of the transition between the terms. A new curriculum was developed in 1936 as a result of the renewal efforts on that curriculum. The 1936 curriculum was criticized on the grounds that it provided teachers with a mere content list and failed to make connections in and among mathematical concepts. Such criticisms led to the development of the 1948 curriculum. However, the 1948 curriculum was criticized as it was mainly concerned with the transmission of a heavy content and hence with mainly the learners' cognitive development. Despite intense criticisms, it has been in use for a period of 20 years until 1968.

The 1968 curriculum, which was one of the first fruits of the scientific curriculum development approaches in the history of the Republic, introduced many innovations. These include preparation and planning for units and topics, investigative learning approach, assignment of responsibilities to students for their own learning processes, bringing the concepts of argumentation and evaluation into the educational system (Gözütok, 2003). Curriculum development activities were performed collectively for all lessons at primary school level until 1968 after which curriculum development efforts focused on each lesson separately. The first mathematics curriculum was prepared in 1983 based on the curriculum model published on the Journal of Notification (no: 2142; dated 1983) and it was put into practice in the 1985-1986 academic year after some preliminary works (Demirel, 1999). The 1983 curriculum involved much more details than ever before. The objectives of the mathematics lesson were expressed as behaviours in order to make them measurable and the topics were grouped as units for the first time in that curriculum.

Curriculum development efforts intensified in 1990s due to the integration of primary and secondary levels under an 8-year primary education program. The 1990 curriculum included primary school as a whole consisting of eight years and the topics and units were organized accordingly. When the compulsory education was extended to eight years in 1997, a new eight-year curriculum was issued in 1998. It can be said that the 1990 and 1998 curricula were highly similar to the 1983 curriculum in terms of content and developmental approach. However, it is seen that the amount of behaviour expressions decreased especially in the 1998 curriculum. The curricula developed in 1990s were criticized on the grounds that they involved many similarities with the 1968 curriculum, did not reflect scientific and technological advances, the objectives and arrangements regarding the teaching-learning process could not keep up with the current developments (Karakaya, 2004). Taking these criticisms into account, efforts for developing a new curriculum accelerated again in early 2000s.

The curriculum developed in 2004 and tested for one year across the country were put into practice in 2005. The expression "behaviour" was abandoned in that curriculum and 
objectives were determined for each unit and topic. Exemplary tasks and activities were provided for all lessons; and various assessment and evaluation methods depending on the objectives were also presented. The objectives included in the 2004 primary education curricula were determined at different thinking levels varying from the recall of information to synthesis (Ulutaş\&Erman, 2012). The curricula that were put into practice as of 2005-2006 academic year have undergone many small changes in time.

It was decided to gradually cease the implementation of the 2005 curriculum starting from the first grade as of 2016-2017 academic year under the resolution of the Head Council of Education and Morality numbered 55 and dated July 28, 2015. It was decided to put into practice the Primary School Mathematics Curriculum that was developed in 2015 in accordance with the compulsory primary education extended to 12 years and rearranged as $4+4+4$. The 2015 curriculum is the first and only curriculum in which primary school education has been arranged as 4 years since the declaration of the Republic. Furthermore, this curriculum is striking in that it has a compact structure as opposed to the curricula developed since 1983. Also the content is presented in learning units on the basis of which the objectives are developed.

\section{Method}

Throughout the republican period, as detailed above, there were ten official primary school mathematics curricula documents. All the official documents except for the 1924 curriculum are put to examination through the content analysis method in order to identify the roles assigned to the teachers. The 1924 curriculum was exempted from the analysis as it was a transitional document whose arranged version was issued in 1926.

The data consists of the general explanations obtained from the written documents of the 1926, 1936, 1948, 1968, 1983, 1990, 1996, 1996, 2005, and 2015 primary school mathematics curricula. The data were examined through content analysis method. Open and selective coding (Strauss \& Corbin, 1990), as the first stages of content analysis, were used during the analyses. For the analysis process we operationalize 'teacher role' as the tasks and responsibilities given to teachers for teaching mathematics; and the works, actions and duties expected from them. This operational definition guided the content analysis. The dataset was examined line by line in conformity with this definition and teacher role codes were created according to the meanings obtained directly or indirectly. Those codes were reviewed and teacher role codes that were considered to serve the same purpose were gathered together, thus forming teacher role categories. Direct citations were used in order to explain how the deductions and results were obtained. Teacher role categories and codes are given in a comparative manner in the primary school mathematics curricula of 1926 to 2015.

Expert opinions were received about coding in order to ensure reliability of the research results during the analysis process. Written documents related to the curricula were submitted to an expert in the field. The coding performed by the expert in line with the research objective was compared with coding performed by the researchers, designating agreements and disagreements. The coding raising disagreements were discussed until all the parties reached an agreement. 


\section{Findings}

The analysis of the primary school mathematics curricula revealed that only the 2005 primary school mathematics curriculum included teacher roles under a separate topic. On the other hand, it was observed that various roles were defined for teachers in the teachinglearning process in all primary school mathematics curricula from 1926 to 2015 . The findings are given in Table 1 below.

Table 1. Codes and categories of teacher roles

\begin{tabular}{|c|c|c|c|c|c|c|c|c|c|c|}
\hline $\begin{array}{c}\text { Role } \\
\text { Categories }\end{array}$ & Teacher Role Codes & 1926 & 1936 & 1948 & 1968 & 1983 & 1990 & 1998 & 2005 & 2015 \\
\hline \multirow{6}{*}{$\begin{array}{l}\text { Teacher Roles } \\
\text { Related to the } \\
\text { Problem } \\
\text { Solving }\end{array}$} & $\begin{array}{l}\text { Developing problem } \\
\text { posing skills }\end{array}$ & $\sqrt{ }$ & - & $\sqrt{ }$ & $\sqrt{ }$ & $\sqrt{ }$ & $\sqrt{ }$ & $\sqrt{ }$ & $\sqrt{ }$ & $\sqrt{ }$ \\
\hline & $\begin{array}{l}\text { Having daily life problems } \\
\text { solved }\end{array}$ & $\sqrt{ }$ & $\sqrt{ }$ & $\sqrt{ }$ & $\sqrt{ }$ & $\sqrt{ }$ & $\sqrt{ }$ & $\sqrt{ }$ & $\sqrt{ }$ & $\sqrt{ }$ \\
\hline & $\begin{array}{l}\text { Having students solving } \\
\text { problems on their own } \\
\text { ways }\end{array}$ & $\sqrt{ }$ & $\sqrt{ }$ & $\sqrt{ }$ & $\sqrt{ }$ & $\sqrt{ }$ & $\sqrt{ }$ & $\sqrt{ }$ & $\sqrt{ }$ & $\sqrt{ }$ \\
\hline & $\begin{array}{l}\text { Having error analysis } \\
\text { carried out during problem } \\
\text { solving processes }\end{array}$ & - & $\sqrt{ }$ & $\sqrt{ }$ & $\sqrt{ }$ & $\sqrt{ }$ & $\sqrt{ }$ & $\sqrt{ }$ & $\sqrt{ }$ & $\sqrt{ }$ \\
\hline & $\begin{array}{l}\text { Appreciating original } \\
\text { solutions developed for } \\
\text { problems }\end{array}$ & - & $\sqrt{ }$ & $\sqrt{ }$ & $\sqrt{ }$ & $\sqrt{ }$ & - & - & $\sqrt{ }$ & $\sqrt{ }$ \\
\hline & $\begin{array}{l}\text { Having suitable strategies } \\
\text { selected and implemented }\end{array}$ & - & - & - & - & - & - & - & $\sqrt{ }$ & $\sqrt{ }$ \\
\hline \multirow{4}{*}{$\begin{array}{l}\text { Teacher Roles } \\
\text { forEstablishin } \\
\mathrm{g} \\
\text { Mathematical } \\
\text { Connections }\end{array}$} & $\begin{array}{l}\text { Making connections } \\
\text { between conceptual and } \\
\text { operational knowledge }\end{array}$ & - & - & - & $\sqrt{ }$ & - & - & $\sqrt{ }$ & $\sqrt{ }$ & $\sqrt{ }$ \\
\hline & $\begin{array}{l}\text { Having inter-operational } \\
\text { relations discovered }\end{array}$ & - & - & $\sqrt{ }$ & $\sqrt{ }$ & $\sqrt{ }$ & $\sqrt{ }$ & $\sqrt{ }$ & $\sqrt{ }$ & $\sqrt{ }$ \\
\hline & $\begin{array}{l}\text { Encouraging students to } \\
\text { use different types of } \\
\text { representation }\end{array}$ & - & - & - & $\sqrt{ }$ & $\sqrt{ }$ & $\sqrt{ }$ & $\sqrt{ }$ & $\sqrt{ }$ & $\sqrt{ }$ \\
\hline & $\begin{array}{l}\text { Relating mathematics to } \\
\text { the other subject areas }\end{array}$ & $\sqrt{ }$ & $\sqrt{ }$ & $\sqrt{ }$ & $\sqrt{ }$ & $\sqrt{ }$ & $\sqrt{ }$ & $\sqrt{ }$ & $\sqrt{ }$ & $\sqrt{ }$ \\
\hline \multirow{3}{*}{$\begin{array}{l}\text { Teacher Roles } \\
\text { in } \\
\text { Mathematical } \\
\text { Communicati } \\
\text { on Process }\end{array}$} & $\begin{array}{l}\text { Getting students sharing } \\
\text { knowledge/ideas among } \\
\text { themselves }\end{array}$ & $\sqrt{ }$ & $\sqrt{ }$ & $\sqrt{ }$ & $\sqrt{ }$ & $\sqrt{ }$ & - & - & $\sqrt{ }$ & $\sqrt{ }$ \\
\hline & $\begin{array}{l}\text { Writing and using } \\
\text { mathematical symbols } \\
\text { appropriately }\end{array}$ & $\sqrt{ }$ & $\sqrt{ }$ & $\sqrt{ }$ & $\sqrt{ }$ & $\sqrt{ }$ & $\sqrt{ }$ & $\sqrt{ }$ & $\sqrt{ }$ & $\sqrt{ }$ \\
\hline & $\begin{array}{l}\text { Making students observe } \\
\text { others' strategies and } \\
\text { designate deficiencies }\end{array}$ & - & - & - & - & - & - & - & - & $\sqrt{ }$ \\
\hline \multirow{3}{*}{$\begin{array}{l}\text { Teacher Roles } \\
\text { Related to } \\
\text { Reasoning }\end{array}$} & $\begin{array}{l}\text { Having inductive } \\
\text { deductions via } \\
\text { observations }\end{array}$ & $\sqrt{ }$ & $\sqrt{ }$ & $\sqrt{ }$ & $\sqrt{ }$ & $\sqrt{ }$ & $\sqrt{ }$ & $\sqrt{ }$ & $\sqrt{ }$ & $\sqrt{ }$ \\
\hline & $\begin{array}{l}\text { Having students making } \\
\text { predictions }\end{array}$ & - & $\sqrt{ }$ & $\sqrt{ }$ & $\sqrt{ }$ & $\sqrt{ }$ & $\sqrt{ }$ & $\sqrt{ }$ & $\sqrt{ }$ & $\sqrt{ }$ \\
\hline & $\begin{array}{l}\text { Having mathematical } \\
\text { reasoning performed }\end{array}$ & - & $\sqrt{ }$ & $\sqrt{ }$ & $\sqrt{ }$ & $\sqrt{ }$ & $\sqrt{ }$ & $\sqrt{ }$ & $\sqrt{ }$ & $\sqrt{ }$ \\
\hline
\end{tabular}


Table 1. Codes and categories of teacher roles (Continued)

\begin{tabular}{|c|c|c|c|c|c|c|c|c|c|c|}
\hline $\begin{array}{c}\text { Role } \\
\text { Categories } \\
\end{array}$ & Teacher Role Codes & 1926 & 1936 & 1948 & 1968 & 1983 & 1990 & 1998 & 2005 & 2015 \\
\hline \multirow{2}{*}{$\begin{array}{l}\text { Teacher } \\
\text { Roles in } \\
\text { Ensuring } \\
\text { Equity } \\
\end{array}$} & $\begin{array}{l}\text { Taking cultural } \\
\text { differences into account }\end{array}$ & - & - & - & - & - & - & - & - & $\sqrt{ }$ \\
\hline & $\begin{array}{l}\text { Taking individual } \\
\text { differences into account }\end{array}$ & - & $\sqrt{ }$ & $\sqrt{ }$ & $\sqrt{ }$ & $\sqrt{ }$ & $\sqrt{ }$ & $\sqrt{ }$ & $\sqrt{ }$ & $\sqrt{ }$ \\
\hline \multirow{4}{*}{$\begin{array}{l}\text { Teacher } \\
\text { Roles in } \\
\text { Remediation } \\
\text { ofStudent } \\
\text { Learning } \\
\text { Deficiencies }\end{array}$} & $\begin{array}{l}\text { Determining learning } \\
\text { deficiencies and } \\
\text { preparing additional } \\
\text { learning experiences }\end{array}$ & - & $\sqrt{ }$ & $\sqrt{ }$ & $\sqrt{ }$ & $\sqrt{ }$ & $\sqrt{ }$ & $\sqrt{ }$ & $\sqrt{ }$ & $\sqrt{ }$ \\
\hline & $\begin{array}{l}\text { Determining learning } \\
\text { difficulties and } \\
\text { intervening }\end{array}$ & - & $\sqrt{ }$ & $\sqrt{ }$ & $\sqrt{ }$ & $\sqrt{ }$ & $\sqrt{ }$ & $\sqrt{ }$ & $\sqrt{ }$ & $\sqrt{ }$ \\
\hline & $\begin{array}{l}\text { Working on } \\
\text { misconceptions }\end{array}$ & - & - & - & - & - & - & - & - & $\sqrt{ }$ \\
\hline & $\begin{array}{l}\text { Intervening sufficiently } \\
\text { when necessary }\end{array}$ & $\sqrt{ }$ & - & $\sqrt{ }$ & $\sqrt{ }$ & $\sqrt{ }$ & $\sqrt{ }$ & $\sqrt{ }$ & $\sqrt{ }$ & $\sqrt{ }$ \\
\hline \multirow{8}{*}{$\begin{array}{l}\text { Teacher } \\
\text { Roles in } \\
\text { Creating an } \\
\text { Efficient } \\
\text { Learning } \\
\text { Environment }\end{array}$} & $\begin{array}{l}\text { Getting active student } \\
\text { participation }\end{array}$ & - & $\sqrt{ }$ & $\sqrt{ }$ & $\sqrt{ }$ & $\sqrt{ }$ & $\sqrt{ }$ & $\sqrt{ }$ & $\sqrt{ }$ & $\sqrt{ }$ \\
\hline & $\begin{array}{l}\text { Creating opportunities for } \\
\text { students' knowledge } \\
\text { construction (e.g } \\
\text { generalizations, } \\
\text { connections etc.) }\end{array}$ & - & $\sqrt{ }$ & $\sqrt{ }$ & $\sqrt{ }$ & $\sqrt{ } *$ & $\sqrt{ } *$ & $\sqrt{ } *$ & $\sqrt{ }$ & $\sqrt{ }$ \\
\hline & $\begin{array}{l}\text { Creating opportunities for } \\
\text { students to learn by doing } \\
\text { and experiencing }\end{array}$ & $\sqrt{ }$ & $\sqrt{ }$ & $\sqrt{ }$ & $\sqrt{ }$ & $\sqrt{ }$ & $\sqrt{ }$ & $\sqrt{ }$ & $\sqrt{ }$ & $\sqrt{ }$ \\
\hline & $\begin{array}{l}\text { Making arrangements for } \\
\text { the transfer of } \\
\text { mathematical knowledge } \\
\text { and skills }\end{array}$ & $\sqrt{ }$ & - & $\sqrt{ }$ & $\sqrt{ }$ & $\sqrt{ }$ & $\sqrt{ }$ & $\sqrt{ }$ & $\sqrt{ }$ & $\sqrt{ }$ \\
\hline & $\begin{array}{l}\text { Making students } \\
\text { collaborate }\end{array}$ & - & - & $\sqrt{ }$ & $\sqrt{ }$ & - & - & - & $\sqrt{ }$ & - \\
\hline & $\begin{array}{l}\text { Performing revision and } \\
\text { consolidation exercises }\end{array}$ & $\sqrt{ }$ & $\sqrt{ }$ & $\sqrt{ }$ & $\sqrt{ }$ & $\sqrt{ }$ & $\sqrt{ }$ & $\sqrt{ }$ & - & - \\
\hline & $\begin{array}{l}\text { Making use of } \\
\text { information and } \\
\text { communication } \\
\text { technologies }\end{array}$ & - & - & - & - & - & - & $\sqrt{ }$ & $\sqrt{ }$ & $\sqrt{ }$ \\
\hline & $\begin{array}{l}\text { Using models for } \\
\text { teaching }\end{array}$ & $\sqrt{ }$ & $\sqrt{ }$ & $\sqrt{ }$ & $\sqrt{ }$ & $\sqrt{ }$ & $\sqrt{ }$ & $\sqrt{ }$ & $\sqrt{ }$ & $\sqrt{ }$ \\
\hline
\end{tabular}

*Detection of inconsistency between the general explanations about the indicated code and the implementation process 
Table 1. Codes and categories of teacher roles (Continued)

\begin{tabular}{|c|c|c|c|c|c|c|c|c|c|c|}
\hline $\begin{array}{c}\text { Role } \\
\text { Categories } \\
\end{array}$ & Teacher Role Codes & 1926 & 1936 & 1948 & 1968 & 1983 & 1990 & 1998 & 2005 & 2015 \\
\hline \multirow{4}{*}{$\begin{array}{l}\text { Teacher Roles } \\
\text { in Developing } \\
\text { Thinking } \\
\text { Skills }\end{array}$} & $\begin{array}{l}\text { Developing critical } \\
\text { thinking skills }\end{array}$ & - & - & - & - & $\sqrt{ }$ & $\sqrt{ }$ & $\sqrt{ }$ & $\sqrt{ }$ & $\sqrt{ }$ \\
\hline & $\begin{array}{l}\text { Developing creative } \\
\text { thinking skills }\end{array}$ & - & - & - & $\sqrt{ }$ & $\sqrt{ }$ & $\sqrt{ }$ & $\sqrt{ }$ & $\sqrt{ }$ & $\sqrt{ }$ \\
\hline & $\begin{array}{l}\text { Developing metacognitive } \\
\text { knowledge and skills }\end{array}$ & - & - & - & - & - & - & - & - & $\sqrt{ }$ \\
\hline & $\begin{array}{l}\text { Developing self-regulation } \\
\text { knowledge and skills }\end{array}$ & - & - & - & - & - & - & - & $\sqrt{ }$ & - \\
\hline \multirow{4}{*}{$\begin{array}{l}\text { Teacher Roles } \\
\text { Regarding } \\
\text { Achievement } \\
\text { of } \\
\text { Mathematical } \\
\text { Objectives }\end{array}$} & $\begin{array}{l}\text { Having mental operations } \\
\text { performed }\end{array}$ & $\sqrt{ }$ & $\sqrt{ }$ & $\sqrt{ }$ & $\sqrt{ }$ & $\sqrt{ }$ & $\sqrt{ }$ & $\sqrt{ }$ & $\sqrt{ }$ & $\sqrt{ }$ \\
\hline & Assigning homework & $\sqrt{ }$ & $\sqrt{ }$ & $\sqrt{ }$ & $\sqrt{ }$ & $\sqrt{ }$ & $\sqrt{ }$ & $\sqrt{ }$ & $\sqrt{ }$ & - \\
\hline & $\begin{array}{l}\text { Modeling psycho-motor } \\
\text { skills }\end{array}$ & - & $\sqrt{ }$ & $\sqrt{ }$ & $\sqrt{ }$ & $\sqrt{ }$ & $\sqrt{ }$ & $\sqrt{ }$ & $\sqrt{ }$ & $\sqrt{ }$ \\
\hline & $\begin{array}{l}\text { Making students get faster } \\
\text { in calculations }\end{array}$ & $\sqrt{ }$ & $\sqrt{ }$ & $\sqrt{ }$ & $\sqrt{ }$ & $\sqrt{ }$ & $\sqrt{ }$ & $\sqrt{ }$ & - & - \\
\hline \multirow{2}{*}{$\begin{array}{c}\text { Teacher Roles } \\
\text { in Improving } \\
\text { Affective } \\
\text { Qualities }\end{array}$} & $\begin{array}{l}\text { Developing the sense of } \\
\text { aesthetics }\end{array}$ & $\sqrt{ }$ & $\sqrt{ }$ & $\sqrt{ }$ & $\sqrt{ }$ & $\sqrt{ }$ & $\sqrt{ }$ & $\sqrt{ }$ & $\sqrt{ }$ & $\sqrt{ }$ \\
\hline & $\begin{array}{l}\text { Motivating students to } \\
\text { learn mathematics }\end{array}$ & - & $\sqrt{ }$ & $\sqrt{ }$ & $\sqrt{ }$ & $\sqrt{ }$ & $\sqrt{ }$ & $\sqrt{ }$ & $\sqrt{ }$ & $\sqrt{ }$ \\
\hline
\end{tabular}

Table 1 shows the roles defined for teachers in the primary school mathematics curricula during the Republican Period. In what follows, the role categories will be scrutinized under separate headings.

\section{Teacher Roles Related to the Problem Solving}

The first category is problem solving under which six roles are identified. It was detected that the role of developing problem posing skills was included in all curricula except the 1936 curriculum. This role was defined with various tasks such as posing similar problems after teaching a subject or posing problems using daily life situations. It was detected that the roles of having students solving problems on their own ways and having daily life problems solved were included in all primary school mathematics curricula from 1926 to 2015. Having daily life problems solved was, for instance, expressed in the 1936 curriculum (p.157)"The problem should be taken from the life and surroundings of the child as much as possible." The role of having students solving problems on their own ways was expressed in the 1990 curriculum (p.27) as "The teacher should let students solve problems by themselves whenever possible." It was observed that error analysis, an important element in successful completion of problem solving, was included in all curricula. Teachers were expected to make students perform evaluations by examining the correct solutions; engaging students in whole class discussions or having them check the plausibility of the solution as part of error analysis. It was determined that appreciating original solutions was defined as a teacher role in all except for the 1926, 1990 and 1998 curricula. The statement "The teacher should appreciate the solutions found by students on their own" $(1968$, p. 17) can be given as an example for this. It was determined that the role of having suitable strategies selected and implemented started to be directly expressed in the 2005 curriculum. In this regard, teachers were asked to make students perform self-evaluations for problem solving processes.

\section{Teacher Roles for Establishing Mathematical Connection}

Four different roles were determined as part of teacher roles regarding mathematical connections. Making connections between conceptual and operational knowledge were 
clearly expressed in the 1968, 1998, 2005 and 2015 curricula. A statement, for example, from the 1998 curriculum articulates this role as "After the meanings of concepts are learned, they should be supported with operational knowledge. Then conceptual and operational knowledge should be related" (p.5). Relating mathematics to the other subject areas was an expectation from teachers in all primary school curricula. It was stressed that teachers should establish connections with lessons such as painting, (life) sciences and social studies. Having inter-operational relations discovered was stressed in all curricula from 1948 to 2015. In this sense, teachers were asked to draw attention to inter-operational relations by emphasizing, for instance, multiplication as a quick addition in equal groups and subtraction as the opposite of addition. The role of making students use different types of representation was mentioned in the 1968 curriculum for the first time. This role was included in all curricula from 1968 onwards; but it was directly expressed in the 2005 curriculum for the first time.

\section{Teacher Roles in Mathematical Communication Process}

Three roles were defined as part of teacher roles in mathematical communication processes: appropriate use of symbols, knowledge sharing and observation of other strategies. It was observed that the role of having students using symbols correctly was included in all curricula. This role was expressed in the 1948 curriculum as "Importance should be attached to explaining problems with symbols, figures and drawings" (p. 182). The role of ensuring knowledge sharing among students was included in all curricula except for the 1990 and 1998 curricula. With this regard, it was expressed, for example, in the 2005 curriculum that "Classroom environments should be organized such that where students can easily share their ideas about problem solving with their peers and teachers" (p. 11). The role of making students observe other strategies and determine their deficiencies was included in the 2015 curriculum for the first time. In this regard, teachers were expected to make arrangements so that their students can observe reasoning and strategy of others and determine deficiencies.

\section{Teacher Roles Related to Reasoning}

Teacher roles related to reasoning included inductive deductions, making predictions and employment of mathematical reasoning. Having inductive deductions made through observations was defined as a teacher role in all primary school curricula. The statement "Sufficient observation shall be made before reaching the main ideas and it shall be ensured that children reach general ideas by themselves" $(1968, p .22)$ can be given as an example of how this role was described in the curricula. All curricula since 1936 have included the role of having mathematical reasoning performed. This role was directly stated in some of the primary school mathematics curricula as part of the general objectives and it was indirectly expressed with implementation process explanations and activity samples in the others. The role of making predictions was included in all curricula from 1936 to 2015. Accordingly, teachers were expected to get students making predictions as to the accuracy of the operations and the solution of the problems.

\section{Teacher Roles in Ensuring Equity}

The teacher roles in ensuring equity in the teaching-learning process included considerations of the cultural and individual differences. The role of taking individual differences into account and making necessary arrangements was included in all curricula from 1936 to 2015. Teachers were required to take the levels, interests, abilities and needs of students into account. Taking cultural differences into account and making relevant arrangements was included in the 2015 curriculum for the first time. In this sense, the 2015 curriculum could be considered to be more comprehensive than the others. 


\section{Teacher Roles in Remediation of Student Learning Deficiencies}

Four different roles were defined as part remediation of student deficiencies. The roles of determining learning deficiencies/difficulties and making appropriate interventions (or preparing additional learning experiences) were included in all curricula from 1936 onwards. The statement "Teachers should easily determine deficiencies of students through periodical observations and measurements. Accordingly, the behaviours that have been poorly developed or not developed at all should be acquired to the students with the additional works" in the 1990 curriculum can be given as an example for that matter. The statement that "Teachers should find out the reasons for the deficiencies of students in and out of the classroom and educate them with various precautions" (p. 161) in the 1936 curriculum can be given another example. The findings about the role of intervening sufficiently when necessary showed that it was included in all but the 1936 curriculum. The statement "The teacher should let students solve a problem on their own as much as possible and should not intervene unless it is necessary. However, it is quite natural for the teacher to help children when a new problem is being handled and it is necessary to use operations that have not been fully understood yet for solving the problem" (1948, p. 182) can be given as an example for this. Working on misconceptions was defined as a teacher role for the first time in the 2015 curriculum. Accordingly, teachers were asked to take students (mis)conceptions into account while making arrangements in the teaching-learning process.

\section{Teacher Roles in Creating an Efficient Learning Environment}

Ten roles were defined with regard to creating an efficient learning environment. Getting active student participation was assigned as a role to teachers in all except for the 1926 curriculum. However, it was observed that this role was weakly established in the 1948, 1968, 2005 and 2015 curricula. In the first glance, this feature was emphasized in the 1983, 1990 and 1998 curricula. Detailed examination of the written documents of these three curricula revealed that students' active participation was intended to be obtained via such activities as getting students taking notes or making them repeat the information orally after teacher. Hence, it could be said that active participation was mainly envisioned to strengthen the domination of teacher during the class time in these three curricula.

The role of creating opportunities for students' knowledge construction such as reaching generalizations and making connections was included in all curricula from 1936 onwards. In this sense, a student-oriented teaching-learning approach was adopted and teachers were asked to act as guides and make arrangements so that students could achieve knowledge construction. However, although the 1983, 1990 and 1998 curricula involve similar perspectives reflected in general explanations, detailed examination showed that teachers were to teach with the duty of making arrangements so that students obtain the information presented to them instead of mainly constructing the knowledge on their own.

The analysis also showed that the roles of student learning by doing and experiencing, use of models for teaching, arrangement of content from the simple to complex were included in all curricula under examination. The roles of creating environments where students could learn by doing and experiencing was expressed as "The teacher shall help students expand their experiences by providing them with opportunities for working with highly diversified materials" (p. 178) in the 1948 curriculum.

The role of making arrangements for the transfer of mathematical knowledge and skills was also included in all curricula except for the 1936 curriculum. Accordingly, teachers were expected to make arrangements so that students could use the acquired knowledge and skills 
both in daily life and in other subject areas. The role regarding enhancing student collaboration was clearly expressed in the 1948, 1968 and 2005 curricula. Performing revision and consolidation exercises was included in all curricula issued between 1926 and 1998. This role had a multi-purpose arrangement such as overcoming learning difficulties through exercises and making students perform faster calculations. The role of forming relations with past experiences of students was included in all curricula from 1936 to 2015 . The statement "The [already existing] knowledge, skills and opinions of students should be used to make sense of new experiences and situations" (p. 18) in the 2015 curriculum can be given as an example for an indication of this role. Making use of information and communication technologies was defined as a teacher role in all curricula from 1998 to 2015. This role was attributed to teachers for the first time in the 1998 (p.5) curricula with the statement "Materials such as calculator, computer, videocassette etc. should be brought to classroom whenever possible".

\section{Teacher Roles in Developing Thinking Skills}

The roles related to the development of critical thinking, creative thinking, selfregulation and metacognitive knowledge and skills were aimed to get students acquiring thinking skills. Developing creative and critical thinking skills were defined as teacher roles in all primary school curricula from 1948 to 2015 and from 1968 to 2015 respectively. The role of developing self-regulation knowledge included in the 2005 curriculum for the first time was excluded from the 2015 curriculum; and the role of developing metacognitive knowledge and skills was integrated into the 2015 curriculum.

\section{Teacher Roles Regarding Achievement of Mathematical Objectives}

Four roles were determined with regard to the achievement of mathematical objectives. The role of having mental operations performed has taken place in all curricula since 1926. Accordingly, improving student skills to perform mental operations was an important emphasis in all the curricula under examination. The role of assigning homework was included in all primary school curricula from 1926 to 2005. This was expressed with various statements such as"...teachers may assign investigative homework that can be performed outside the classroom" (1968, p. 18), and as "It should be paid attention not to assign too many exercises and problems to students [as a homework] to perform outside the lessons"(1990, p. 27; 1983, p. 20; 1968, p. 18) in the curricula. The role of making students faster in calculations was mentioned in all primary school curricula between 1926 and 1998. The extract "Exercises for conducting accurate and fast operations should be performed after the relevant operation is understood"(p. 10) can be given as an example for this role. The role of modeling psycho-motor skills was included in all curriculum from 1936 to 2015. Modeling often aimed to demonstrate how to use tools such as ruler, square, divider and to explain how to draw geometric shapes such as circle. In doing so teachers were expected to perform teaching through getting students to make practice.

\section{Teacher Roles in Improving Affective Qualities}

The roles of motivating students to learn mathematics and developing the sense of aesthetics were adopted as teacher roles in improving affective qualities. The role of motivating students to learn mathematics was included in all primary school mathematics curricula from 1936 onwards. Take, for example, the statement from the 2005 curriculum "Student motivation should be taken into account... It should be paid attention to improve motivation of students to learn mathematics by taking their individual differences into account" (p. 19). Developing the sense of aesthetics has been a task expected from teachers in all primary school mathematics curricula since 1926. The findings about developing the sense 
of aesthetics showed that this role was usually mentioned directly in the general objectives of the curricula.

\section{Discussion}

This study examined the teacher roles assigned by the primary mathematics curricula applied during the Republican period. The findings provide important clues for understanding the policies about and approaches to teaching mathematics to young learners in this period. We presents our observations for that matter under separate subheadings below.

\section{Teacher roles and process skills}

The most striking result of the analyses is that the roles assigned to teachers in the curricula coincide with mathematical process skills which are at the center of reform movements in the international arena. The process skills explained in the Principles and Standards for School Mathematics published by the National Council of Teachers of Mathematics (NCTM) in 2000were as follows: Problem Solving, Reasoning and Proof, Communication, Connections and Representation. Acquisition of these skills is deemed necessary for an effective use of mathematical knowledge. Importance of these skills started to be widely recognized only in the 2000s in international curriculum development efforts especially as a result of the reform movements of the early 1980s (van de Walle, Karp \& BayWilliams, 2010).

It is noteworthy that teacher roles aimed at improvement of these skills began to be defined as of the first years of the Republic in the primary school mathematics curricula. The curricula included arrangements in parallel with the aforementioned skills and relevant teacher roles have been defined. The problem solving skill has been a significant part of the curricula since 1926. In this regard, problem posing skills, solution of daily life problems and appreciation of original solutions were emphasized among the roles assigned to teachers in almost all curricula in the Republican Period. Meta-analyses carried out in the field of problem solving revealed significant effects of these features on student success and on developing positive attitude towards mathematics (e.g. Rosli et al., 2014). However, it is interesting that selection and implementation of appropriate strategies in the problem solving process were included only after the 2005 curriculum. This matter was neglected in the earlier curricula.

Among the roles, solution of daily life problems deserves particular attention as it is an important teacher role that was persistently emphasized in all curricula of the Republican period. Studies show that relating the school mathematics to the daily life and solution of daily life problems are among the primary objectives of mathematics teaching and a significant source of motivation for students to learn mathematics (Lappan et al., 2002; Mosvold, 2008). In this sense, curricula's approach to problem solving (and thus mathematics teaching) could be said to have included arrangements reflecting the importance of this matter throughout the Republican history.

There are three important and complementary roles related to problem solving assigned to teachers: having students solve problems on their own ways, analyzing errors and appreciating original solutions. These roles support students' autonomy in mathematics learning, reflective thinking and creativity (Leikin\& Pitta-Pantazi, 2013; Hagger et al., 2015). Hence it can be said that the roles assigned to teachers within the scope of problem solving in mathematics teaching in the Republican period are highly important and they include arrangements about teaching of mathematics that coincide with the current approaches. However, we believe, it is a noteworthy deficiency that no role was defined in the 1990 and 
1998 curricula for appreciating original solutions.

Another process skill detected in the curricula is establishing mathematical connections. Conceptual understanding of new mathematical knowledge, realization of meaningful learning and effective use of mathematics in various situations are closely related to this skill (Star \&Stylianides, 2013; Kilpatrick et al., 2001). Furthermore, it is pointed out that establishing connections makes it possible for students to see the integrity of mathematics and understand its function better (NCTM, 2000). The findings of this study revealed that connecting mathematics with other subject areas was attached a particular importance in the curricula throughout the history of the Republic and thus relevant roles were defined for teachers. The role regarding the discovery of inter-operational relationships (e.g. multiplication is a repeated addition) was defined for teachers for the first time in the 1948 curriculum. Emphasizing different representations (diagram, table, symbols etc.) of mathematical concepts was assigned to teachers as a role starting from the 1968 curriculum. There have been some fluctuations in teacher role for making connections between the conceptual and operational knowledge throughout the history of the Republic. Despite a clear emphasis placed on the importance of this matter in the 1968 curriculum, this role excluded from the 1983 and 1990 curricula; we think such exclusion was a significant deficiency compensated only in the 1998 curriculum. It can be said that these two curricula focused mainly on operational skills and were relatively ignorant of conceptual learning.

Mathematical communication is another process skill for which roles are detected through our analysis. Communication in mathematics can take place in various forms whether it be spoken or written. Studies (e.g. Cooke \& Buchholz, 2005) have shown that ability of students to talk and/or write about mathematics can improve their mathematical ideas. It was observed that the mathematics curricula determined teacher roles in order to encourage students to share their mathematical ideas. This was a particular emphasis of the curricula (except for the 1990 \& 1998) along with the appropriate use of mathematical symbols. It was detected that a role related to having students analyzing the ways of thinking and strategies used by their friends was assigned in the 2015 curricula as different from the others.

Another process skill encountered in the curricula is related to reasoning. Reasoning includes intellectual processes such as making deductions using available information, explaining reasons for expressed opinions in a mathematical (logical) manner, and combining various opinions about the same phenomenon in a whole (Umay, 2003; Brodie, 2010; Altun, 2010). Having inductive deductions via observations has been a role emphasized in all curricula especially for geometry teaching. Children's own experiences and informal deductions at early ages have been considered a significant factor in reasoning (Schultz-Ferrell et al., 2007). From this point of view, it can be said that the curricula placed special emphasis on making use of deductions while teaching geometric shapes in particular (for instance, "teaching the concept of cube by making students examine various boxes, dices, cube sugar, cardboard or paperboard and wooden models" 1948, p.205). Further to this, the curricula put emphasis on roles in order to support the development of students' reasoning and prediction skills such as guessing the result without solving the problem or guessing the number of a certain amount of objects without counting. Although prediction and reasoning were explained in a very detailed manner especially in the 2005 curriculum, they were mentioned superficially in the others. 


\section{Equity and remediation of learning deficiencies}

The teacher roles included in the curricula focused on other important matters apart from mathematical process skills. Roles ensuring equity and remediation of learning deficiencies stand out among these matters. The roles determined for taking individual differences into account and making relevant arrangements constitute a significant component of the equity principle specified in the NCTM (2000) standards. However, the details given about the arrangements related to individual differences and relevant roles also include significant differences across the curricula. For example, although individual differences were discussed under a separate heading and explained in detail in the 1968 curriculum, they were just the form of passing-by citations in many others. The requirement for taking cultural differences into account is mentioned only in the 2015 curriculum.

The curricula are concerned with the determination and remediation of student learning deficiencies; and while doing so, the curricula expected teachers to support student autonomy. In order to express this, it is stated almost in all curricula that unnecessary and excessive intervention must be avoided and sufficient intervention is recommended when necessary. Nevertheless, the requirement for determining mathematical difficulties experienced by students and intervening in an appropriate manner is mentioned very superficially in the curricula. Making efforts in order to eliminate misconceptions of students is mentioned only in the 2015 curriculum (though very superficially). Overcoming student difficulties, misconceptions and learning deficiencies is a subject that maintains its importance in today and calls for complicated interventions (Bingölbali\&Özmantar, 2009). Nevertheless, existence of the roles in the Republican curricula regarding these areas for teachers is of great importance.

\section{Roles for effective learning}

There are also some other roles defined to make arrangements for promoting effective learning. Some of these roles (getting active student participation, creating opportunities for knowledge construction, learning by doing and experiencing) are related to active involvement of students in taking charge of their own learning. These roles are explicitly emphasized in the curricula (except for 1926). On the other hand, the 1983, 1990 and 1998 curricula, in contrast to the others, emphasized active participation of students while adopting a teacher-oriented approach. In these three curricula, active participation of students in the process was handled with a reductionist approach (e.g., answering the questions asked by the teacher, taking notes, receiving and orally repeating the presented information). Therefore, it can be said that those curricula included arrangements that fell well behind the previous ones. For instance, the 1968 curriculum's emphasis on reaching generalizations through students own efforts (a similar emphasis is present directly or indirectly in the others), description of relevant tasks as well as sample practices indicate a student participation way ahead of those three curricula.

Although it was observed that the role of making students collaborate as a practice supporting active participation had an important place in the 1948, 1968 and 2005 curricula, they could not make their way into the curricula of 1983, 1990 and 1998. More interestingly, student collaboration was not defined as a role in the 2015 curriculum even though its importance for social, cognitive and academic development of students is well-established with the relevant research (e.g. Plass et al., 2013; Unlu\&Aydintan, 2011).

Transfer of mathematical knowledge and skills is another role given to the teachers. Transfer could be described as an adaptation of knowledge to the new forms, contents and familiar or 
unfamiliar situations (Schunk, 1996). We come across the role of making arrangements for a transfer of knowledge and skills in all curricula except for the 1936. The issue of transfer has long been an issue that attracts research attention and has been studied in philosophical, epistemological, pedagogical and psychological grounds (Hiebert, 2013; McKeough et al., 2013).Though cognitively difficult, researchers appear to have an agreement that transfer of knowledge is somehow related to the permanent learning. This role regarding the transfer can be interpreted as an emphasis of curriculum developers on the pragmatic aspect of teaching mathematics. Furthermore, the fact that such a cognitively difficult process could make its way into the curricula can be considered as an indication of the importance attached to the outputs of mathematics learning-teaching process.

Performing revision and consolidation exercises is an important role included in all curricula except for the 2005 and 2015. Homework and exercises were seen important especially in the curricula developed until 1968. The intention of revision and consolidation was often to make learning more durable and usable; but it was also intended, particularly after 1983, to perform operations faster. It might be due to the oft-cited associations with the behavioural learning theory (Senemoğlu, 2005; Gündoğdu, 2007; Schunk, 1996), this role excluded from the 2005 and 2015 curricula. However, recent studies (e.g. Tabach, Hershkowitz, \& Schwarz, 2006; Monaghan \&Özmantar, 2006; Dreyfus \&Tsamir, 2004) have presented convincing evidence that revision and consolidation exercises may have a function that serves permanent learning provided that they are planned in a purposeful and associative manner.

We come across making use of information and communication technologies as a role ensuring effective learning. Rapidly emerging technological advances brought along different tools and software in mathematics teaching that were not present before. The relevant studies have provided convincing evidence regarding the fact that technology can change the way of thinking of and approaching to mathematics (See Akkoç, 2015). These studies have also showed that the understanding of students about mathematical concepts and relations are affected positively if technology is used appropriately (See Caulfield et al., 2005). It is seen that roles related to the use of technology were mentioned in the last three curricula (1998, 2005 and 2015) in parallel with the technological advancements.

It is frequently pointed out in mathematical curricula that mathematics has an abstract nature and this makes its teaching difficult. In order to overcome this difficulty, teachers were advised to make use of models, relate the concepts to the students' past experiences and arrange the content from the simple to complex. In this regard, it is requested to perform teaching by making use of concrete and semi-concrete entities, objects and images. Furthermore, it is pointed out that teaching based on concrete and real life experiences of students would make mathematics concrete.

\section{Roles for the development of (mathematical) thinking skills}

Another category of teacher roles is related to the development of thinking skills for students. These roles aimed at improvement critical thinking, creative thinking, metacognitive and self-regulatory knowledge and skills. Development of such thinking skills is particularly desired by high level policy documents of Turkish power elites such as the Strategic Plan of the Ministry of National Education; the Tenth Development Plan; Resolutions of the Supreme Council for Science and Technology. These documents emphasize that sustainable social development is dependent on individuals with such thinking skills and hence a great prominence is given to the acquisition of these skills. The role of improving creative thinking has become an important element of mathematics teaching since the 1968 curriculum. Roles 
have been defined since 1983 for improving the critical thinking skill. We think that the inclusion of the metacognitive thinking skills in the 2015 curriculum is an overdue but favourable development. On the other hand, exclusion of the self-regulation skills from the 2015 curriculum is a significant deficiency. Also we consider it a deficiency not to include skills such as entrepreneurship and innovativeness present in the Strategic Plan of the Ministry of National Education in the 2015 curriculum.

Among the roles defined in order to realize mathematical objectives, we come across the role of having mental operations performed as a feature that has remained the same throughout the history of the Republic. The role of making students faster in calculations seemed to be an ideal that found a place in all the curricula except for 2005 and 2015.

\section{Teacher roles and affective qualities}

Two roles stand out in relation to improvement of affective qualities: developing students' sense of aesthetics and motivating them to learn mathematics. These two roles were constantly emphasized in almost all curricula. It has been considered important to like and enjoy mathematics since the 1936 curriculum. Omission of affective qualities in the teachinglearning processes has been frequently criticized in the relevant literature (Wells, 1999). Therefore, it is important for us to see that curricula of the Republican period also deal with the affective dimensions of learning (for a more detailed examination of curricula in terms of affective qualities, see Bozkurt\&Esendemir, 2015).

\section{Final remarks}

There have been changes in certain areas regarding teacher roles in the curricula in the light of new developments and technological advances. Taking cultural differences into account and making relevant arrangements, making efforts in order to overcome misconceptions, making use of information and communication technologies, having students select problem solving strategies and improving thinking skills are the areas where the changes are most striking. On the other hand, there is a general stability in Republican period's approach to teaching mathematics to younger learners. Furthermore, it was found out that significant roles whose importance has been widely accepted by studies have been included in the curricula throughout the history of the Republic (e.g. making students solve daily life problems). It is considered that it will be useful to determine the roles assigned to teachers in the curricula in the form of standards by following the up-to-date developments more closely.

\section{Acknowledgement}

We would like to thank GülayAgaç for her contributions during the analysis of the official curricula documents.

\section{References}

Akkoç,

H.

İlkokulmatematiköğretimprogramlarınınbilgiveiletişimteknolojileribağlamındaincelen mesi [An investigation of primary school mathematics curriculum within the context of information and communication technology]. In M. F. Özmantar, A. Öztürk\& E, Bay (Eds.), Reform vedeğişimbağlamindailkokulmatematiköğretimprogramları [Primary school mathematics curriculum within context of reform and change] ( $p$. 407-424). Ankara: PegemAkademi Publication. 
Altun, M. (2010).illkögrretim 2.kademe (6., 7., 8. Sinıflarda) matematiköğretimi [Teaching of Mathematics in 6th-8th Grades]. Bursa: Alfa AktüelAkademi.

Bingölbali, E., \&Özmantar, M. F. (2009).Matematikselzorluklarveçözümönerileri [Mathematical challenges and solution proposals]. Ankara: PegemAkademi Publication.

Bozkurt,

A., $\quad$ \&Esendemir,

O. (2015).Duyuşsalözelliklerbağlamındailkokulmatematikdersiöğretimprogramlarınıninc elenmesi [An investigation of primary school mathematics curriculum within the context of affective characteristics]. In M. F. Özmantar, A. Öztürk\& E, Bay (Eds.), Reform vedeğişimbağlamindailkokulmatematiköğretimprogramlarl [Primary school mathematics curriculum within context of reform and change] (p. 407-424). Ankara: PegemAkademi Publication.

Brodie, K. (2010). Teaching mathematical reasoning in secondary school classrooms.London: Springer.

Caulfield, R., Smith, P. E., \& McCormick, K. (2005). The spread sheet: A vehicle for connecting proportional reasoning to the real world in a middle school classroom. In W. Masalskiand\& P. Elliott (Eds.), Technology-supported mathematics learning environments: Sixty seventh year book. Reston, VA: National Council of Teachers of Mathematics.

Cooke, B. D., \& Buchholz, D. (2005). Mathematical communication in the classroom: A teacher makes a difference. Early Childhood Education Journal, 32(6), 365-369.

Darling-Hammond, L. (1998). Teachers and teaching: Testing policy hypotheses from a national commission report. Educational Researcher, 27(1), 5-15.

Demirel, O. (1999). Kuramdanuygulamayaeğitimde program geliştirme.[Curriculum development in education from theory to practice]. Ankara: PegemAkademi Publication.

Demirel, O. (2006). Eğitimde program geliştirme [Curriculum development in education]. Ankara: PegemAkademi Publication.

Dreyfus, T., \&Tsamir, P. (2004). Ben's consolidation of knowledge structures about infinite sets. Journal of Mathematical Behaviour, 23(3), 271-300.

Ergün, M. (2009).Eğitimfelsefesi [Philosophy of education]. Ankara: PegemAkademi Publication.

Ergün, M., Özmantar, M. F., Bay, E., \&Agaç, G. (2015). Cumhuriyetinilanindangünümüzeeğitimde,

geliştirmedevematematikprogramlarındayaşanandeğişimvegelişimler [From the declaration of the Republic to today, changes and developments in education, curriculum development and mathematics programs]. In M. F. Özmantar, A. Öztürk\& $\mathrm{E}$, Bay (Eds.), Reform vedeğişimbağlamindailkokulmatematiköğretimprogramları [Primary school mathematics curriculum within context of reform and change] ( $p$. 407-424). Ankara: PegemAkademi Publication.

Gözütok, F. D. (2003). Türkiye'de program geliştirmeçalışmaları [Curriculum Development studies in Turkey].MilliEğitimDergisi [Journal of National Education], 160.

Gündoğdu, H. M. (2007). Bağlantıkuramı [Attachment theory]. A. Kaya (Ed.), Ĕgitimpsikolojisi [Educational psychology]. Ankara: PegemAkademi Publication.

Hagger, M. S., Sultan, S., Hardcastle, S. J., \&Chatzisarantis, N. L. (2015). Perceived autonomy support and autonomous motivation toward mathematics activities in educational and out-of-school contexts is related to mathematics homework behaviour and attainment. Contemporary Educational Psychology, 41, 111-123.

Han, C. (2013). Teachers' functional paradigms and educational reform.Trakya University Journal of Education, 3(1), 59-79. 
Henson, K. T. (2006). Curriculum planning: Integrating multiculturalism, constructivism, and education reform. Long Grove IL: Waveland Press.

Hiebert, J. (Ed.) (2013). Conceptual and procedural knowledge: The case of mathematics. New York: Routledge.

Karakaya, S. (2004).Eğitimde program geliştirmeçalışmalarıveyeniyönelimler [Curriculum development studies and new trends in education]. Ankara: Asil Release Distribution.

Kilpatrick, J., Swafford, J. O., \&Findell, B. (2001).Adding it up: Helping children learn mathematics. Washington, DC: National Academy Press.

Klapper, M. H., Berlin, D. F., \& White, A. L. (1994). Professional development: Starting point for systemic reform. Cognosos, 3(3), 1-5.

Lappan, G.,Fey, J. T., Fitzgerald, W. N., Friel, S. N., \& Phillips, E. D. (2002). Getting to know connected mathematics: An implementation guide. Glenview, IL: PrenticeHall.

Leikin, R., \& Pitta-Pantazi, D. (2013). Creativity and mathematics education: The state of the art. ZDM, 45(2), 159-166.

Mayer, R. (2002). The promise of educational psychology, Volume II: Teaching for meaningful learning. Upper Saddle River, NJ: Prentice Hall.

McKeough, A., Lee, J., \& Marini, A. (Eds.) (2013).Teaching for transfer: Fostering generalization in learning. New York: Routledge.

MilliEğitimBakanlığıTalimveTerbiyeKuruluBaşkanlığı (MEB-TTKB) [Ministry of National Education-Head Council of Education and Morality] (1990).ilkögretimmatematikdersiprogramı [Primary school mathematics curriculum]. Ankara: MEB [Ministry of National Education].

MilliEğitimBakanlığıTalimveTerbiyeKuruluBaşkanlığı (MEB-TTKB) [Ministry of National Education-Head Council of Education and Morality] (1998).Illkögretimokulumatematikdersiögretimprogramı [Primary school mathematics curriculum]. Ankara: MEB [Ministry of National Education].

MilliEğitimBakanlığıTalimveTerbiyeKuruluBaşkanlığı (MEB-TTKB) [Ministry of National Education-Head Council of Education and Morality] (2005).Illkögretimmatematik program [Primary school mathematics curriculum]. Ankara: MEB [Ministry of National Education].

MilliEğitimBakanlığıTalimveTerbiyeKuruluBaşkanlığı (MEB-TTKB) [Ministry of National Education-Head Council of Education and Morality] (2015).ilkögretimmatematikdersi (1, 2, 3 ve 4.Sinıflar) ögretimprogramı [Primary school mathematics curriculum (1st, 2nd, 3rd and 4th Grades)]. Ankara: MEB [Ministry of National Education].

MilliEğitimBakanlığı (MEB) [Ministry of National Education] (1948). Illkokulprogramı [Primary school curriculum]. Istanbul: MilliEğitimBasımevi [National Education Printing House].

MilliEğitimGençlikveSporBakanlığı (MEB) [Ministry of National Education, Youth and Sports] (1968).Illkokulmatematikprogramı [Primary school mathematics curriculum]. Ankara: MEB [Ministry of National Education].

MilliEğitimGençlikveSporBakanlığı (MEB) [Ministry of National Education, Youth and Sports] (1983).Illkokulmatematikprogramı [Primary school mathematics curriculum]. Ankara: MEB [Ministry of National Education].

Monaghan, J.,\&Ozmantar, M. F. (2006). Abstraction and consolidation.Educational studies in mathematics, 62, 233-258.

Mosvold, R. (2008). Real-life connections in Japan and the Netherlands: National teaching patterns and cultural beliefs. International Journal for Mathematics Teaching and Learning.Retrieved fromhttp://www.cimt.plymouth.ac.uk/journal/mosvold.pdf 
National Council for Curriculum and Assessment (NCCA). (1999). Mathematics: Primary school curriculum (Dublin: Stationery Office). Retrieved fromhttp://www.ncca.ie/uploadedfiles/Curriculum/Maths_Gline.pdf

National Council of Teacher of Mathematics (NCTM).(2000). Principles and standarts for school mathematics. Reston, VA: NCTM.

National Council of Teacher of Mathematics (NCTM). (2014). National curriculum in England: Mathematics programmes of study. Retrieved fromhttps://www.gov.uk/government/publications/national-curriculum-in-englandmathematics-programmes-of-study/national-curriculum-in-england-mathematicsprogrammes-of-study

Ormrod, J. E. (2003). Educational psychology: Developing learners (4th ed.). Upper Saddle River, NJ: Merrill Prentice Hall.

Ornstein, A. C., \&Hunkins, F. P. (2004).Curriculum: Foundations, principals and issues (4th ed.). Boston: Allyn\& Bacon.

Plass, J. L., O’Keefe, P. A., Homer, B. D., Case, J., Hayward, E. O., Stein, M., \&Perlin, K. (2013). The impact of individual, competitive, and collaborative mathematics game play on learning, performance and motivation.Journal of Educational Psychology, 105(4), 1050-1066.

Rosli, R., Capraro, M. M., \&Capraro, R. M. (2014). The effects of problem posing on student mathematical learning: A meta-analysis. International Education Studies, 7(13).

Schultz-Ferrell, K., Hammond, B., \& Robles, J. (2007).Introduction to reasoning and proof grades prek-2. (The math process standards series, Ed. Susan O'connell) Portsmouth: Heinemann.

Schunk, D. H. (1996). Learning theories. PrinticeHallInc., New Jersey.

Senemoğlu, N. (2005). Gelişimöğrenmeveöğretim: Kuramdanuygulamaya (12. Bask1) [Development, learning and teaching: Theory into practice]. Ankara: Gazi Bookstore.

Sönmez, V. (2002).Eğitimfelsefesi [Philosophy of Education]. Ankara: Anı Publication.

Star, J. R., \&Stylianides, G. J. (2013). Procedural and conceptual knowledge: Exploring the gap between knowledge type and knowledge quality. Canadian Journal of Science, Mathematics, and Technology Education, 13(2), 169-181.

Strauss, A., \& Corbin, J. (1990).Basic of qualitative research: Grounded theory procedures and techniques. Newbury Park and London: Sage.

Tabach, M., Hershkowitz, R., \& Schwarz, B. B. (2006). Constructing and consolidating of algebraic knowledge with in dyadic processes: A case study. Educational Studies in Mathematics, 63, 235-258.

TürkiyeCumhuriyetiMaarifVekaleti. [Republic of Turkey Ministry of National Education] (1930). Ilk mektepmüfredatprogramı [Primary school mathematics curriculum].İstanbul: DevletMatbaas1 [Istanbul: Government Printing Office].

TürkiyeCumhuriyetiKültürBakanlığ1 [Republic of Turkey Ministry of Culture] (1936).Ilkokulprogramı [Primary school curriculum].İstanbul: DevletBasımevi [Istanbul: Government Printing Office].

Ulutaş, S., \&Erman, E. (2012). Measurement and Evaluation in the Curriculums of High School Education Applied in Turkey from the Establishment of the Republic Onward. Turkish Journal of Education, 1(1).

Umay, A. (2003). Mathematical reasoning skill. Hacettepe University Faculty of Education Journal, 24, 234-243.

Ünlü, M., \&Aydıntan, S. (2011). The Effect of Cooperative Learning Method on the Student's Success and Recall Levels of the 8 th Grade Students Learning in Permutation and Probability Subject. Journal of Kırşehir Education Faculty, 12(3), 116. 
Van de Walle, J., Karp, K. S., \& Bay-Williams, J. M. (2010).Elementary and middle school mathematics: teaching developmentally (7th ed.). Boston: Allyn\& Bacon.

Walmsley-Angela L. E. (2003). A history of the new mathematics movement: Its relationship with current mathematical reform. Lanham, MD: University Press of America.

Wells, G. (1999). Dialogic inquiry: Towards a sociocultural practice and theory of education. Cambridge: Cambridge University Press. 